\title{
Pemberdayaan Bimbingan Perkawinan dalam Mewujudkan Keluarga Sakinah
}

Muhammad Hatami Ritonga
Universitas Islam Negeri (UIN) Sunan Kalijaga, Yogyakarta, Indonesia

\section{Pendahuluan}

Problem pernikahan dan rumah tangga banyak sekali, mulai dari sekedar pertengkaran kecil sampai ke perceraian dan keretakan rumah tangga yang menyebabkan broken home. Penyebab dapat terjadi karena berbagai alasan seperti awal pembentukan rumah tangga pada masa-masa sebelum terjadinya pernikahan, karena faktor ekonomi, ketidak cocokan antara suami isteri, perbedaan status sosial, tuntutan keluarga, tidak terpenuhinya kebutuhan biologis, ketidak harmonisan dan lain sebagainya. ${ }^{1}$

${ }^{1}$ Siti Djazimah and Muhammad Jihadul Hayat, 'Pelaksanaan Kursus Pranikah Di Kota Yogyakarta: Urgensitas, Efektivitas Hukum, Dan Tindakan Sosial', Al-Ahwal: Jurnal Hukum Keluarga Islam, 11.1 (2019), 59 <https:// doi.org/10.14421/ahwal.2018.11105>. 
Problem muncul pada saat mengarungi kehidupan rumah tangga, dengan kata lain ada faktor internal (datang dari suami/isteri) misalnya watak atau kepribadian yang berbeda maupun faktor eksternal (faktor dari luar individu) misalnya campur tangan pihak luar terhadap keluarga tersebut, baik dari kalangan keluarga itu sendiri maupun dari masyarakat sosial, sehingga tidak seperti yang diharapkan dimana keluarga seyogyanya dilimpahi sakinah. Perkawinan merupakan ikatan lahir batin antara seorang pria dan wanita sebagai suami isteri dengan tujuan untuk membentuk keluarga yang bahagia dan kekal berdasarkan Ketuhanan Yang Maha Esa. Tujuan utama perkawinan adalah untuk memperoleh kehidupan yang tenang (ketenangan) (Sakinah). Perkawinan akan menimbulkan rasa saling mencintai antara suami isteri, saling menyayangi antara orang tua dan anak-anaknya dan antara anggota keluarganya, maka dengan sendirinya insya Allah tercipta pula ketenangan, cinta dan kasih saing. ${ }^{2}$

Badan Penasihat Pembinaan dan Pelestarian Perkawinan (BP4) adalah suatu organisasi yang bersifat profesi, sebagai penunjang tugas Kementrian Agama dalam bidang penasehatan perkawinan dan pembinaan keluarga bahagia sejahtera. Tujuan BP4 untuk mempertinggi mutu perkawinan dan mewujudkan keluarga bahagia, atau Sakinah dan kekal menurut Islam. Lembaga ini sebagai pelaksana keputusan konferensi Departemen Agama di Tretes Jawa Timur tanggal 25-30 Juni 1955 maka disatukanlah organisasi tersebut dengan nama "Badan Penasihatan Perkawinan dan Penyelesaian Perceraian", melalui keputusan Menteri Agama No. 85 tahun 1961. BP4 sebagai badan penunjang tugas Kementrian Agama, merupakan bagian dari Direktorat Bimbingan Masyarakat Islam, memberikan nasehat perkawinan, perselisihan dan perceraian bagi suami isteri yang mengalami krisis rumah tangga. Pasangan yeng telah melakukan konsultasi dengan BP4, diharapkan dalam mengelola kehidupan rumah tangga mereka seperti yang diharapkan yaitu rumah tangga yang Sakinah. ${ }^{3}$

Tugas BP4 adalah menasehati, mengarahkan dan membimbing calon mempelai untuk menuju keluarga yang sakinah. Keluarga sakinah adalah keluarga bahagia, sejahtera yang tercukupi kebutuhan lahir dan batin. Dalam prakteknya masih banyak keluhan dari masyarakat, yakni salah satu anggota keluarga yang tidak lain adalah masalah ketidakharmonisan dalam rumah tangga, begitupun pelanggaran-pelanggaran terhadap aturan-aturan yang sudah ditentukan, seperti terjadinya perkawinan di bawah umur, kawin siri,

${ }^{2}$ Moh. Afandi, 'Hukum Perceraian Di Indonesia: Studi Komparatif Antara Fikih Konvensional, UU Kontemporer Di Indonesia Dan Negara-Negara Muslim Perspektif HAM Dan CEDAW', $A L$ AHWAL Jurnal Hukum Keluarga Islam, Vol.7.No. 2 (2014), 191-201.

${ }^{3}$ Desi Asmaret, Alaiddin Koto, and Afrizal M, 'Transformasi Hukum Keluarga Islam Di Indonesia: Telaah Pemikiran Rifyal Ka'bah', Al-Ahwal: Jurnal Hukum Keluarga Islam, 12.2 (2020), $145<$ https://doi.org/10.14421/ahwal.2019.12203>. 
kawin kontrak, terlebih yang sering terjadi di masyarakat adalah perceraian, hal ini berdampak terhadap perlindungan hak-hak keturunan hasil pernikahan tersebut.

\section{Metode Penelitian}

Jenis penelitian ini adalah penelitian lapangan (field research), yaitu data yang diambil untuk dijadikan rujukan dalam penelitian ini adalah fakta-fakta di lapangan. Dalam hal ini yaitu data-data tentang program dan pelaksanaan pemberian nasehat terhadap pasangan calon mempelai yang diperoleh dari BP4 KUA Gondokusuman Yogyakarta. Penelitian ini juga didukung dengan penyusunan pustaka (library research), yaitu penyusunan yang dilakukan di perpustakaan dan dilangsungkan dengan cara membaca, menelaah, atau memeriksa bahan-bahan keperpustakaan yang terdapat di suatu perpustakaan. ${ }^{4}$

Sifat penelitian ini adalah deskriptif-analitik yaitu penelitian yang menuturkan, menganalisa dan mengklasifikasi data secara kualitatif (menurut mutu dan kualitasnya). Metode ini dapat diartikan sebagai prosedur pemecahan masalah yang diteliti berdasarkan fakta-fakta yang tampak. Teknik pengumpulan data yang digunakan penyusun dalam penyusunan ini yaitu Wawancara dan Dokumentasi. Wawancara dilakukan untuk memperoleh data dari responden melalui tanya jawab secara langsung dengan para petugas KUA diantaranya ada 4 (empat) orang yang diwawancarai mereka adalah petugas Badan Penasehat Pembinaan dan Pelestarian Perkawinan (BP4) KUA Gondokusuman Yogyakarta. Dokumentasi merupakan metode pengumpulan data dimana penyusun mengumpulkan data dengan menelusuri beberapa arsip-arsip atau dokumendokumen seperti undang-undang, anggaran dasar anggaran rumah tangga BP4 serta dokumen-dokumen lain yang ada hubungannya terkait dengan hal yang detail, yakni masalah problematika BP4 di KUA Gondokusuman Yogyakarta. ${ }^{5}$

Analisis yang digunakan dalam penyusunan ini adalah analisis kualitatif, secara sistematik kemudian diinterpretasikan ke dalam lapangan sesuai dengan keadaan sebenarnya yang ditemui di lapangan setelah mendapatkan data atau gambaran tentang upaya BP4 Gondokusuman dan hasil yang dicapai dari upaya tersebut. Data didapat dari hasil interview atau wawancara dan dokumen kemudian diseleksi, dipelajari dan dipahami dengan seksama kemudian diambil kesimpulan. Dalam mencari atau mendapatkan kesimpulan penyusun menggunakan metode induktif, yaitu cara berfikir yang berangkat dari faktafakta khusus dan peristiwa-peristiwa kongkret kemudian digeneralisasikan. ${ }^{6}$

${ }^{4}$ L Kajoko, Zaidah Nur Rosidah, and I.G.A.K. Rachmi Handayani, 'Refleksi Paradigma Ilmu Pengetahuan Bagi Pembangunan Hukum Pengadaan Tanah', Bestuur, 7.1 (2019), 1-14 <https://jurnal.uns.ac.id/bestuur/article/view/42694>.

${ }^{5}$ Zaidah Nur Rosidah, 'Coherence of the Rules of Sharia Against Pancasila', Bestuur, 8.1 (2020), 40 <https:/ / doi.org/10.20961/bestuur.v8i1.42723>.

6 I.G.A.K. Rachmi Handayani, Lego Karjoko, and Abdul Kadir Jaelani, 'Model Pelaksanaan Putusan Mahkamah Konstitusi Yang Eksekutabilitas Dalam Pengujian Peraturan Perundang- 


\section{III.Pembahasan}

\section{Persoalan Perceraian di Indonesia}

Perkawinan amat penting dalam kehidupan manusia, perseorangan maupun kelompok. Dalam perkawinan yang sah, pergaulan antara laki-laki dan perempuan terjadi secara terhormat sesuai kedudukan manusia sebagai makhluk yang berkehormatan. Pergaulan hidup berumah tangga dibina dalam suasana damai, tenteram dan rasa kasih sayang antara suami isteri. Anak keturunan dari hasil perkawinan yang sah menghiasi kehidupan keluarga dan sekaligus merupakan kelangsungan hidup manusia secara bersih dan berkehormatan. Keluarga yang terbentuk melalui perkawinan antara seseorang laki-laki dan perempuan, merupakan perpaduan dari dua orang tersebut yang setuju untuk meraih kebahagiaan. Oleh karena itu, mencapai tujuan perkawinan pada prinsipnya sama dengan mencapai kebahagiaan anggota keluarga. Anggota keluarga pada awalnya adalah suami dan isteri. Setelah berketurunan mereka mempunyai anak, maka anggota keluarga bertambah dengan anak. ${ }^{7}$

Realitas tersebut tampaknya hanya melihat dari satu segi, yaitu kebolehan hukum dalam hubungan antara seorang laki-laki dan seorang wanita yang semula dilarang menjadi dibolehkan. Padahal setiap perbuatan hukum itu mempunyai tujuan dan akibat ataupun pengaruhnya. Hal-hal inilah yang menjadikan perhatian manusia pada umumnya dalam kehidupan sehari-hari, seperti terjadinya perceraian, anak yang lahir dari perkawinan hamil, perkawinan yang tidak dicatatkan, dispensasi perkawinan, kurang adanya keseimbangan antara suami dan istri, sehingga memerlukan penegasan arti perkawinan, bukan saja dari kebolehan hubungan seksual tetapi juga dari segi tujuan dan akibat hukumnya. ${ }^{8}$

Konflik dalam perkawinan tidak dapat dipisahkan dari kehidupan manusia, meskipun demikian, masyarakat cenderung menilai konflik sebagai bentuk suatu permusuhan, tindakan agresif, penuh kekerasan dan membuat hubungan tidak berjalan dengan baik. Perceraian atau putusnya perkawinan adalah terputusnya ikatan perkawinan antara seorang pria dengan seorang wanita. putusnya ikatan tersebut dapat diakibatkan oleh salah seorang diantara keduanya meninggal dunia, antara pria dan wanita bercerai, dan salah seorang diantara keduanya sudah pergi meninggalkan kediamannya sehingga pengadilan menganggap bahwa yang bersangkutan sudah meninggal. Perceraian berasal dari kata "cerai". Menurut Kamus Besar Bahasa Indonesia "cerai" merupakan kata kerja yang berarti pisah, putus hubungan

\footnotetext{
Undangan Di $\quad$ Indonesia',
< https://jurnal.uns.ac.id/bestuur/article/view/42700>.

7.1

(2019),

$36-46$

${ }^{7}$ Muhammad Jihadul Hayat, 'Problematika Kewarisan Di Masyarakat Lombok Timur: Kajian Faktor Dan Alasan Berperkara Di Pengadilan Agama Selong.', 1.2 (2015).

${ }^{8}$ Muhammad Jihadul Hayat, 'Muhammad Jihadul Hayat Vol. 3 No. 1 Tahun 2018', 3.1 (2018), 49-63.
} 
sebagai suami istri. Dalam istilah ilmu Fikih, perceraian dikenal dengan sebutan "talak" atau "Furqah". Talak berarti membuka ikatan atau membatalkan perjanjian atau segala bentuk perceraian yang dijatuhkan oleh pihak suami. Terjadinya perceraian berdampak pada beberapa hal, antara lain kewajiban Iddah bagi isteri, hak Ruju' bagi suami, kewajiban nafkah atas anak dan lain sebagainya. ${ }^{9}$

Dalam konteks rumah tangga, konflik dianggap sebagai awal terjadinya permusuhan, disharmoni hingga perceraian. Berdasarkan data dari direktorat Peradilan Agama mengenai tingginya jumlah angka perceraian di Indonesia, maka dapat dilihat pada tabel sebagai berikut:

Tabel 1

Data Direktorat Jenderal Peradilan Agama

\begin{tabular}{|l|c|c|}
\hline \multirow{2}{*}{ Tahun } & \multicolumn{2}{|c|}{ Jenis Perceraian } \\
\cline { 2 - 3 } & Cerai Gugat & Cerai Talak \\
\hline 2018 & 307.778 Kasus & 111.490 Kasus \\
\hline 2019 & 355.842 Kasus & 124.776 Kasus \\
\hline
\end{tabular}

Sumber: Direktorat Jenderal Badan Petradilan Agama Mahkamah Agung RI Tahun 2019

Kondisi ini menunjukkan melemahnya terhadap ketahanan keluarga di Indonesia terhadap konflik. Adanya indikasi yang kuat bahwa suami isteri tidak mampu mengelola dan menyelesaikan konflik dalam keluarga. Data tersebut juga menunjukkan bahwa masyarakat lebih memilih menyelesaikan persoalan keluarga di pengadilan daripada menggunakan cara-cara kekeluargaan. Pengadilan sebagai salah satu lembaga penyelesaian perkara dipandang belum mampu menyelesaikan perkaranya sesuai dengan harapan masyarakat. Kritik terhadap lembaga peradilan disebabkan karena beberapa faktor, antara lain; penyelesaian jalur litigasi pada umumnya lambat (waste of time), pemeriksaan sangat formal (formalistic), sangat teknis (technically), biaya yang tinggi (high cost), dan perkara yang masuk pengadilan sudah overloaded. Selain itu, keputuisan pengadilan selalu diakhiri dengan menang dan kalah, sehingga kepastian hukum dipandang merugikan salah satu pihak berperkara. ${ }^{10}$

\section{Pemberdayaan Bimbingan Perkawinan dalam Mewujudkan Keluarga Sakinah}

Cita-cita untuk mewujudkan keluarga sakinah mawaddah wa rahmah sebagaimana disebut dalam KHI atau untuk mewujudkan keluarga yang kekal dan bahagia sebagaimana disebutkan dalam undang-undang perkawinan No. 1

${ }_{9}^{9}$ Universitas Islam and others, 'Praktik Taukil Wali Nikah Masyarakat Adat Sasak Sade', 12.2 (2019), 161-72.

${ }^{10}$ Akbar Sayudi, 'Upaya Perlindungan Korban Tindak Pidana Perkosaan Dalam Sistem Peradilan Pidana Indonesia', FIAT JUSTISIA:Jurnal Ilmu Hukum, 10.1 (2017), 203-20 <https://doi.org/10.25041/fiatjustisia.v10no1.663>. 
Tahun 1974 Tentang Perkawinan merupakan dambaan setiap orang. Namun, untuk menuju kearah tujuan mulia tersebut bukanlah hal yang mudah untuk dicapai, karena dalam menjalani kehidupan perkawinan banyak sekali rintangan yang bisa berujung pada perselisihan yang akhirnya dapat menghapuskan gambaran cita-cita yang di inginkan tersebut. ${ }^{11}$

Berdasarkan Peraturan Menteri Agama No. 3 Tahun 1974 Pasal 28 ayat (3) menyebutkan bahwa Pengadilan Agama dalam berusaha mendamaikan kedua belah pihak dapat meminta bantuan kepada Badan Penasihat Perkawinan Perselisihan dan Perceraian (BP4) agar menasihati kedua suami isteri tersebut untuk hidup makmur lagi dalam rumah tangga. Atas dasar inilah maka dibentuk Badan Penasihatan, Pembinaan Pelestarian Perkawinan (BP4) yang bertujuan untuk memberikan bekal pengetahuan tentang seluk eluk pernikahan dan segala dan segala permasalahannya, serta bertujuan untuk menjadi wadah bagi tempat meminta nasihat, bimbingan dan mediasi bagi pasangan yang memerlukan konseling perkawinan. Dengan demikian, mediasi yang dijalankan di KUA Gondokusuman Yogyakarta adalah untuk pemberdayaan para pihak agar dapat menyelesaikan perkaranya dengan pikiran jernih. Hal tersebut, selain sesuai dengan win-win solution, KUA juga mempunyai itikad yang baik serta berperan langsung dalam upaya perdamaian, dan dalam hal ini diperbolehkan dan sudah sesuai dalam Hukum Islam maupun dalam Hukum positif.

Kuantitas problem manusia semakin tinggi di tengah arus globalisai yang semakin cepat. Kehadiran lembaga atau institusi semacam BP4 menjadi cukup penting karena kebutuhan manusia untuk mendapatkan bantuan dalam penyelesaian persoalan mereka juga meningkat. Meskipun peran BP4, dalam konteks perkainan ini, bukanlah sebuah akhir dari keputusan hukum, tetapi secara biologis dan sosiologis, penasehatan, pembinaan dan usaha-usaha untuk tetap melestarikan perkawinan sangat membantu masyarakat. Sebagaimana dalam perspektif Hukum Islam, perkawinan adalah merupakan ikatan lahir batin antara seorang pria dan wanita sebagai suami isteri dengan tujuan untuk membentuk keluarga yang bahagia dan kekal berdasarkan Ketuhanan Yang Maha Esa, meskipun perceraian diperbolehkan oleh Allah SWT, tetapi dibenci oleh-Nya. Karena itulah peran BP4 hingga saat ini terus dimaksimalkan untuk mengupayakan terbentuknya keluarga yang sakinah mawaddah dan rahmah. Hal ini tidak lain agar nantinya dapat menumbuhkan "tumbuh-tumbuhan yang baik dan menumbuhkan buah yang bagus". ${ }^{12}$

BP4 Gondokosuman sebagai badan penasihatan memang lebih dikhususkan untuk memberikan penasihatan perkawinan, dan biasanya penasihatan ini

${ }^{11}$ Hukum Dalam, Perspektif Maqā, and Ș I D Asy-syarī Ah, 'Pencatatan Perkawinan Sebagai Perlindungan Hukum', 12.1 (2019), 15-28.

${ }^{12}$ Muhammad Iqbal Juliansyahzen, 'Dialektika Hukum Islam Dan Hukum Adat Pada Perkawinan', III.1 (2019), 1-14. 
diberikan kepada para calon pasangan suami isteri yang akan melakukan proses perkawinan yang telah mendaftarkan diri di BP4 Gondokusuman. Namun demikian BP4 Gondokusuman tetap memberikan ruang dan waktu bagi pasangan suami isteri untuk berkonsultasi terkait dengan berbagai permasalahan rumah tangga. Peran BP4 sebagai motivator, harus mampu menjadi daya pendorong atau pengaruh yang kuat agar seseorang bisa melakukan suatu perubahan ke arah yang lebih baik. Maka dari itu sebelum melakukan motivasi kliennya para konselor atau korps penasihatan harus memahami tentang keinginan dan kebutuhan yang dimiliki oleh kliennya. ${ }^{13}$

Upaya dan peran BP4 Gondokusuman dalam menangani permasalahan seputar penasihatan dan perselisihan perkawinan, yang mana dalam hal ini adalah sebagai tugas utama dari BP4, yaitu BP4 sebagai seorang motivator harus memiliki kemampuan dalam mengucapkan kata-kata dengan baik dan benar, selain itu juga seorang penasihat harus mampu menguasai materi-materi penasihatan yang akan disampaikan kepada klien. Jangan sampai klien merasa ragu dengan apa yang sudah dinasihatkan oleh seorang seorang penasihat. Adapun nasihat yang biasa disampaikan oleh korps penasihat adalah mengenai keluarga alam agama, fiqh munakahat, tentang pernikahan yang Islami, tentang undan-undang perkawinan, tentang hukum perkawinan. ${ }^{14}$ dan perceraian, serta tentang hak dan kewajiban suami isteri dalam rumah tangga.

Selain sebagai motivator, BP4 juga harus bisa berperan sebagai fasilitator, yakni memfasilitasi klien dengan senantiasa memberikan pelayanan yang terbaik dan berusaha untuk bisa menjalankan tugas dengan profesional, yang berkaitan dengan sarana prasarana untuk memudahkan proses penasihatan pra nikah, konsultasu keluarga dan penasihatan perceraian sampai pada penyuluhan langsung ke masyarakat. Salah satu tugas dari BP4 adalah mendamaikan, disinilah peran BP4 sebagai mediator sangan diperlukan terutama dalam kasus perselisihan suami isteri yang mana dituntut untuk mampu bertindak sebagai penengah ketika ada perselisihan atau masalah rumah tangga yang dialami oleh pasangan suami isteri. ${ }^{15}$

Peran mediator yang memiliki kredibilitas harus dikuasai oleh BP4, yakni dalam berkomunikasi dapat membuat klien mantap dengan apa yang disampaikan, juga harus memiliki daya tarik agar klien merasa puas dengan

${ }^{13}$ H Hidayatulloh, L Hasan - Jurnal Hukum Keluarga Islam, and undefined 2016, 'Eksistensi Badan Penasehatan Pembinaan Dan Pelestarian Perkawinan (BP4) Dalam Mewujudkan Keluarga Sakinah Di KUA Peterongan Jombang', Journal.Unipdu.Ac.Id, 1.April (2016), 83-98 <http://journal.unipdu.ac.id/index.php/jhki/article/view/611>.

${ }_{14}$ Wawancara dengan Ibu Puji Karyawati, selaku Ketua BP4 KUA Kecamatan Gondokusuman Yogyakarta, tanggal 25 Mei 2015.

${ }^{15}$ Iswantoro Iswantoro, 'Penyelesaian Sengketa Harta Perkawinan Pasca Putusan Mahkamah Konstitusi Nomor 69/Puu-Xiii/2015', Al-Ahwal: Jurnal Hukum Keluarga Islam, 11.1 (2019), 43 <https://doi.org/10.14421/ahwal.2018.11104>. 
masukan-masukan yang telah diberikan oleh tim penasihat., yang paling penting adalah empati, yaitu dapat merasakan apa yang klien keluhkan dan antara penasihat dengan klien merasa bersatu, sehingga klien dapat mengutarakan segala persoalan yang sedang dihadapinya. Kesadaran dalam melaksanakan tugas dan kewajiban dalam keluarga sangatlah penting agar tercipta suasan nyaman, aman, dan tentram, sebaliknya jika kesadaran itu tidak timbul maka dapat menimbulkan masalah yang berkaitan dengan hubungan keluarga terutama suami isteri, dan upaya penasihatan untuk keluarga yang bermasalah itu bersifat refresif, yakni diberikan kepada pasangan suami isteri yang mengalami kegoncangan dalam rumah tangga supaya mereka damai dan tentram. ${ }^{16}$

Tujuan diadakannya penasihatan adalah untuk mencapai kehidupan rumah tangga dalam keadaan tentram, bahagia rukun dan damai lahir batin. Namun tidak jarang apa yang diharapkan tidak sesuai dengan kenyataan yang dihadapinya. Untuk itulah BP4 berusaha memberikan penasihatan agar calon pasangan suami isteri mempunyai bekal untuk memasuki kehidupan rumah tangga yang penuh dengan berbagai tantangan, cobaan serta hal-hal yang tidak diharapkan. Dengan adanya bekal itu diharapkan mereka siap baik mental maupun spritualnya dalam memasuki bahtera kehidupan berumah tangga kelak. ${ }^{17}$

Berdasarkan hasil penyusunan ini, yang termaktub dalam bab sebelumnya, pada realitanya keberadaan BP4 memang sangat membantu. Setidaknya bantuan ini dapat dilihat dalam peran-peran; membantu memecahkan masalah keluarga, mendamaikan suami isteri yang diliputi keinginan perceraian dan memberikan wawasan untuk membina rumah tangga. Kedatangan klien kepada BP4 memberikan gambaran bahwa lembaga semi-resmi ini memiliki fungsi dan peran yang tidak dianggap "berat sebelah". Netralitas ini menguntungkan BP4 untuk menempatkan dirinya sebagai pihak ketiga atau mediator. Dengan posisi tengah itu maka BP4 memang diharapkan untuk memberikan solusi yang adil serta menguntungkan kedua belah pihak yang bertikai, meskipun boleh jadi klien yang pertama menuju meja BP4 adalah salah satu dari mereka. ${ }^{18}$

${ }^{16}$ Euis Nurlaelawati and Arskal Salim, 'Gendering the Islamic Judiciary: Female Judges in the $\begin{array}{lllll}\text { Religious Courts of Indonesia', Al-Jami'ah, } 51.2 & \text { (2014), 247-78 }\end{array}$ <https://doi.org/10.14421/ajis.2013.512.247-278>.

${ }_{17}$ Euis Nurlaelawati, 'Zakat and the Concept of Ownership in Islam: Yusuf Qaradawi's Perspective on Islamic Economics', Al-Jami'ah: Journal of Islamic Studies, 48.2 (2010), 365-85 <https://doi.org/10.14421/ajis.2010.482.365-385>.

${ }^{18}$ Euis Nurlaelawati, 'Pernikahan Tanpa Pencatatan: Isbat Nikah Sebuah Solusi?', Musãwa Jurnal Studi Gender Dan Islam, 12.2 (2013), 261 <https:/ / doi.org/10.14421/musawa.2013.122.261$277>$. 


\section{Penutup}

Berdasarkan hasil penyusunan yang telah dibahas dan disimpulkan bahwa peranan BP4 dalam menangani masalah perkawinan, yaitu dengan cara memberikan penataran/penyuluhan pra nikah maupus sesudah nikah sudah sesuai dengan semangat hukum Islam di mana ia menjadi pihak ketiga (juru damai) sebgai penengah diantara pihak yang berperkara. Peranan BP4 dalam mencegah terjadinya perceraian hanya bersifat membantu menyelesaikan masalah yang dihadapi pasangan suami isteri yang berselisih supaya berdamai, dengan cara diskusi atau wawancara serta memberikan nasihat. Hal tersebut bukan bermaksud mempersulit terjadinya perceraian, melainkan mengulur waktu supaya tidak terlalu tergesa-gesa dalam mengajukan perceraian dan memperbanyak penasihatan supaya pasangan dapat berfikir jernih dalam menceraikan. Selain itu, memberikan layanan konseling bagi keluarga yang dijerat masalah. BP4 juga memberi bimbingan tentang keluarga sakinah, terkait KUA sebagai BP4, upaya yang dilakukan adalah memberi bimbingan pra-nikah, mengadakan seminar mengenai keluarga harmonis, dan membentuk DBKS (Desa Binaan Keluarga Sakinah)

\section{Refrences}

Afandi, Moh., 'Hukum Perceraian Di Indonesia: Studi Komparatif Antara Fikih Konvensional, UU Kontemporer Di Indonesia Dan Negara-Negara Muslim Perspektif HAM Dan CEDAW', AL AHWAL Jurnal Hukum Keluarga Islam, Vol.7.No. 2 (2014), 191-201

Asmaret, Desi, Alaiddin Koto, and Afrizal M, 'Transformasi Hukum Keluarga Islam Di Indonesia: Telaah Pemikiran Rifyal Ka'bah', Al-Ahwal: Jurnal $\begin{array}{lllll}\text { Hukum Keluarga } & \text { Islam, } & 12.2 & \text { (2020), } & 145\end{array}$ <https://doi.org/10.14421/ahwal.2019.12203>

Dalam, Hukum, Perspektif Maqā, and Ș I D Asy-syarī Ah, 'Pencatatan Perkawinan Sebagai Perlindungan Hukum', 12.1 (2019), 15-28

Djazimah, Siti, and Muhammad Jihadul Hayat, 'Pelaksanaan Kursus Pranikah Di Kota Yogyakarta: Urgensitas, Efektivitas Hukum, Dan Tindakan Sosial', AlAhwal: Jurnal Hukum Keluarga Islam, 11.1 (2019), 59 $<$ https:// doi.org/10.14421/ahwal.2018.11105>

Handayani, I.G.A.K. Rachmi, Lego Karjoko, and Abdul Kadir Jaelani, 'Model Pelaksanaan Putusan Mahkamah Konstitusi Yang Eksekutabilitas Dalam Pengujian Peraturan Perundang-Undangan Di Indonesia', Bestuur, 7.1 (2019), 36-46 <https://jurnal.uns.ac.id/bestuur/article/view/42700>

Hayat, Muhammad Jihadul, 'Muhammad Jihadul Hayat Vol. 3 No. 1 Tahun $2018^{\prime}, 3.1$ (2018), 49-63

- - , 'Problematika Kewarisan Di Masyarakat Lombok Timur: Kajian Faktor 
Dan Alasan Berperkara Di Pengadilan Agama Selong.', 1.2 (2015)

Hidayatulloh, H, L Hasan - Jurnal Hukum Keluarga Islam, and undefined 2016,

‘Eksistensi Badan Penasehatan Pembinaan Dan Pelestarian Perkawinan

(BP4) Dalam Mewujudkan Keluarga Sakinah Di KUA Peterongan Jombang', $\begin{array}{llll}\text { Journal.Unipdu.Ac.Id, } & \text { 1.April 83-98 }\end{array}$

<http://journal.unipdu.ac.id/index.php/jhki/article/view/611>

Islam, Universitas, Negeri Mataram, Arif Sugitanata, Universitas Islam, Negeri Sunan, and Kalijaga Yogyakarta, 'Praktik Taukil Wali Nikah Masyarakat Adat Sasak Sade', 12.2 (2019), 161-72

Iswantoro, Iswantoro, 'Penyelesaian Sengketa Harta Perkawinan Pasca Putusan Mahkamah Konstitusi Nomor 69/Puu-Xiii/2015', Al-Ahwal: Jurnal Hukum $\begin{array}{llll}\text { Keluarga Islam, } & 11.1 & \text { (2019), }\end{array}$ <https:/ / doi.org/10.14421/ahwal.2018.11104>

Juliansyahzen, Muhammad Iqbal, 'Dialektika Hukum Islam Dan Hukum Adat Pada Perkawinan', III.1 (2019), 1-14

Kajoko, L, Zaidah Nur Rosidah, and I.G.A.K. Rachmi Handayani, 'Refleksi Paradigma Ilmu Pengetahuan Bagi Pembangunan Hukum Pengadaan $\begin{array}{llll}\text { Tanah', } \quad \text { Bestuur, } & 7.1 & \text { (2019), }\end{array}$ <https:/ /jurnal.uns.ac.id/bestuur/article/view/42694>

Nurlaelawati, Euis, 'Pernikahan Tanpa Pencatatan: Isbat Nikah Sebuah Solusi?', Musãwa Jurnal Studi Gender Dan Islam, $12.2 \quad$ (2013), 261 <https:/ / doi.org/10.14421/musawa.2013.122.261-277>

- - - 'Zakat and the Concept of Ownership in Islam: Yusuf Qaradawi's Perspective on Islamic Economics', Al-Jami'ah: Journal of Islamic Studies, 48.2 (2010), 365-85 <https:/ / doi.org/10.14421/ajis.2010.482.365-385>

Nurlaelawati, Euis, and Arskal Salim, 'Gendering the Islamic Judiciary: Female Judges in the Religious Courts of Indonesia', Al-Jami'ah, 51.2 (2014), 247-78 <https:/ / doi.org/10.14421/ajis.2013.512.247-278>

Rosidah, Zaidah Nur, 'Coherence of the Rules of Sharia Against Pancasila', Bestuur, 8.1 (2020), 40 <https:/ / doi.org/10.20961/bestuur.v8i1.42723>

Sayudi, Akbar, 'Upaya Perlindungan Korban Tindak Pidana Perkosaan Dalam Sistem Peradilan Pidana Indonesia', FIAT JUSTISIA:Jurnal Ilmu Hukum, 10.1 (2017), 203-20 <https:/ / doi.org/10.25041/fiatjustisia.v10no1.663> 